\title{
CIM5 Bubbler: Effect of Sparge Rate and Duration on Homogeneity to Am/Cm Glass
}

by

M. E. Stone

Westinghouse Savannah River Company

Savannah River Site

Aiken, South Carolina 29808

This paper was prepared in connection with work done under the above contract number with the U.S. Department of Energy. By acceptance of this paper, the publisher and/or recipient acknowledges the U.S. Government's right to retain a nonexclusive, royalty-free license in and to any copyright covering this paper, along with the right to reproduce and to authorize others to reproduce all or part of the copyrighted paper. 


\section{DISCLAIMER}

This report was prepared as an account of work sponsored by an agency of the United States Government. Neither the United States Government nor any agency thereof, nor any of their employees, makes any warranty, express or implied, or assumes any legal liability or responsibility for the accuracy, completeness, or usefulness of any information, apparatus, product or process disclosed, or represents that its use would not infringe privately owned rights. Reference herein to any specific commercial product, process or service by trade name, trademark, manufacturer, or otherwise does not necessarily constitute or imply its endorsement, recommendation, or favoring by the United States Government or any agency thereof. The views and opinions of authors expressed herein do not necessarily state or reflect those of the United States Government or any agency thereof.

This report has been reproduced directly from the best available copy.

Available for sale to the public, in paper, from: U.S. Department of Commerce, National Technical Information Service, 5285 Port Royal Road, Springfield, VA 22161, phone: (800) 553-6847, fax: (703) 605-6900 email: orders@ntis.fedworld.gov online ordering: http://www.ntis.gov/ordering.htm

Available electronically at http://www.doe.gov/bridge

Available for a processing fee to U.S. Department of Energy and its contractors, in paper, from: U.S. Department of Energy, Office of Scientific and Technical Information, P.O. Box 62, Oak Ridge, TN 37831-0062, phone: (865)576-8401, fax: (865)576-5728 email: reports@adonis.osti.gov 


\section{DISCLAIMER}

Portions of this document may be illegible in electronic image products. Images are produced from the best available original document. 
WESTINGHOUSE SAVNNAH RIVER COMPANY

WSRC-TR-99-0462TL SAVANNAH RIVER TECHNOLOGY CENTER

Date: $12 / 15 / 99$

TO: W. H. MARTIN, 730-2B

FROM: L. F. LANDQN/704-1T

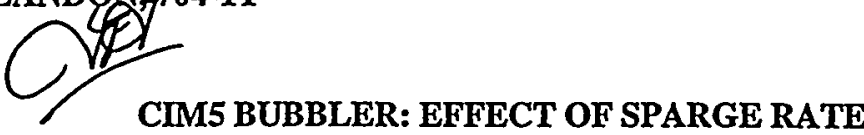
AND DURATION ON HOMOGENEITY OF AM/CM GLASS

The attached document describes the results of the evaluation of the rate of argon sparging and sparge duration on the homogeneity of the final glass product. This work was in response to Task 1.07 of TTR 99MNSS/SE-006. Please refer any questions you may have regarding the contents of this document to M.E. Stone (Ext. 7-7751)

\section{DISTRIBUTION}

J. T. Dahlstrom, 730-1B

A. W. Bowers, 704-10F

A. P. Giordano, 730-1B

A. P. Fellinger, 730-1B

N. H. Harkey, 730-1B

D. C. Witt, 704-1T

M. E. Stone, 704-1T

STI 703-43A (4) 
WSRC-TR-99-00462, Revision 0

\section{CIM5 BUBBLER: EFFECT OF SPARGE RATE AND DURATION ON HOMOGENEITY OF Am/Cm GLASS (U)}

M. E. Stone

Westinghouse Savannah River Company Savannah River Site Aiken, SC 29808

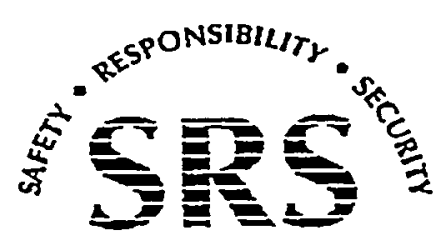

PREPARED FOR THE U.S. DEPARTMENT OF ENERGY UNDER CONTRACT NO. DE-AC09-96SR18500 


\section{DISCLAIMER}

This report was prepared by Westinghouse Savannah River Company (WSRC) for the United States Department of Energy under Contract No. DE-AC09-96SR18500 and is an account of work performed under that contract. Neither the United States Department of Energy, nor WSRC, nor any of their employees makes any warranty, expresses or implied, assumes any legal liability or responsibility for accuracy, completeness, or usefulness, of any information, apparatus, or product or process disclosed herein or represents that its use will not infringe privately owned rights. Reference herein to any specific commercial product, process, or service by trademark, name, manufacturer or otherwise does not necessarily constitute or imply endorsement, recommendation, or favoring of same by WSRC or by the United States Government or any agency thereof. The views and opinions of the authors expressed herein do not necessarily state or reflect those of the United States Government or any agency thereof. 
WSRC-TR-99-00462, Rev.0

ITS Tracking Number:

ITS-99-0100

Keywords: Americium,

Curium, Precipitation,

Vitrification,

Sparge,

Bubbler,

$\mathrm{Am} / \mathrm{Cm}$

Retention: Permanent

\section{CIM5 BUBBLER: EFFECT OF SPARGE RATE AND DURATION ON HOMOGENEITY OF Am/Cm GLASS (U)}

M. E. Stone

Publication Date: December 2, 1999

Westinghouse Savannah River Company

Savannah River Site

Aiken, SC 29808

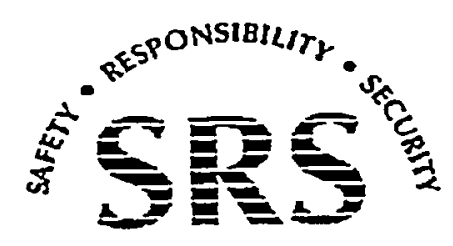

SAVANNAH RIVER SITE

PREPARED FOR THE U.S. DEPARTMENT OF ENERGY UNDER CONTRACT NO. DE-AC09-96SR18500 . 
APPROVALS

\section{$m \varepsilon$ sh}

M. E. Stone, Immobilization Technology Section

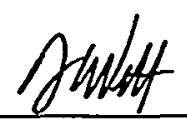

D. C. Witt, Technical Reviewer, Immobilization Technology Section

L. F. Landon, Manager, Immobilization Technology Section $\frac{12 / 9 / 99}{\text { Date }}$

$12 / 9 / 99$

Date

$\frac{12 / 10 / 99}{\text { Date }}$ 


\section{TABLE OF CONTENTS}

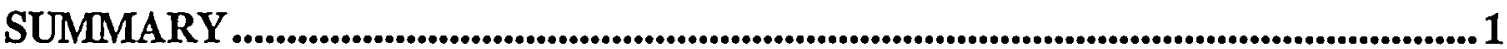

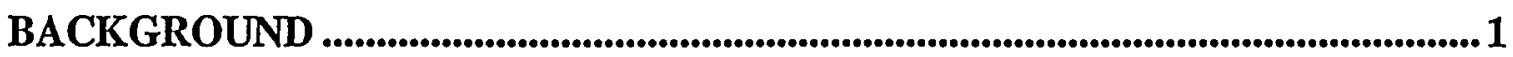

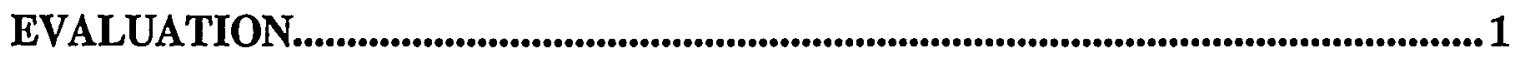

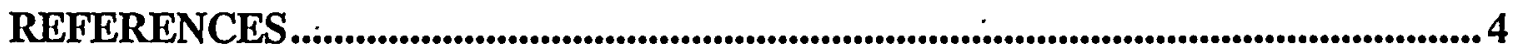

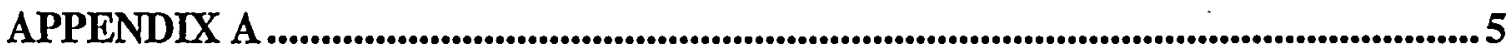

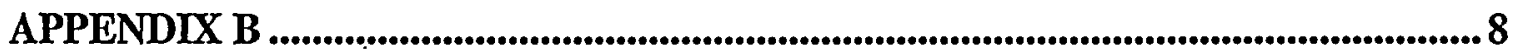




\section{SUMMARY}

The current flowsheet for the $\mathrm{Am} / \mathrm{Cm}$ program requires that the glass pool be sparged with argon during the soaking period immediately prior to draining the melter. The effect of varying sparge rate and duration on the homogeneity of the final glass product was evaluated using the full scale 5" Cylindrical Induction.Melter (CIM5) pilot facility. The tests showed that the homogeneity of the glass product is maintained provided the sparge rate is at least $1.5 \mathrm{scfh}$ and the sparge duration is at least 45 minutes or the flowrate is at least $1.0 \mathrm{scfh}$ and the sparge duration is 60 minutes. SRTC recommends that the melt pool be sparged for 75 minutes with an argon flowrate of $1.5 \mathrm{scfh}$ and a sparge dip tube located 1" from the melter bottom. In addition, pour flowrate was found to be a reliable indication of glass homogeneity.

\section{BACKGROUND}

The $A m / C m$ program will vitrify the americium and curium currently stored in F-canyon. The current flowsheet results in a large variation in lanthanide loading from the bottom to the top of the melt pool unless the glass pool is mixed. The highly loaded glass at the bottom of the melter is susceptible to devitrification at the operating temperature of the drain tube while the lightly loaded glass at the top of the melter has a high viscosity resulting in a glass heel in the melter after pouring. An argon sparge to mix the glass pool was shown to greatly improve homogeneity of the glass during base process development tests (WSRC-TR-99-00434); therefore tests were conducted to determine optimal sparge settings. The argon is bubbled into the melter using a $1 / 4$ " diameter bubbler assembly as shown in Appendix B.

\section{EVALUATION}

Nine test runs were conducted to determine the optimal conditions for sparge rate and duration. The final glass product for all tests was $49 \mathrm{wt} \%$ lanthanide content glass produced from $25 \mathrm{SrABS}$ cullet and surrogate feed oxalate produced in Coupled Precipitator One. The same heatup sequence was used for all runs. The sparge tube was inserted at the beginning of the soak period and the pour sequence was initiated when the desired sparge duration was completed. Argon flow was started prior to insertion of the sparge tube (bubbler) and flow continued until the pour sequence was completed.

All tests were successfully completed without excessive volume expansion, drain tube pluggage, or other process difficulties noted. All pour sequences began cleanly within 30 seconds of pour initiation, all pours terminated cleanly with no strings, and no residual heels were noted after any pour. 30 grams of $49 \mathrm{SrABS}$ cullet was used to seal the drain tube at the conclusion of each pour. The glass poured during each run showed no signs of swirling or devitrification and was generally free of bubbles.

During the pouring process, timed samples were taken at approximately 30 second intervals to determine the pour flowrate. These samples were crushed and ground at TNX, then analyzed for elemental composition by the ITS Mobile Laboratory. Graphs for each run showing pour 
flowrates and lanthanide content of the glass versus pour time are attached in Appendix $A$. The parameters used for each run and the results are shown in Table 1.

Table 1. Run Parameters and Results

\begin{tabular}{|c|c|c|c|c|c|c|c|c|c|}
\hline \multirow[t]{3}{*}{$\begin{array}{c}\text { Run } \\
\#\end{array}$} & \multirow{3}{*}{$\begin{array}{c}\text { Argon } \\
\text { Flowrate } \\
\text { Scfh }\end{array}$} & \multirow{3}{*}{$\begin{array}{c}\text { Sparge } \\
\text { Duration }\end{array}$} & \multirow{3}{*}{$\begin{array}{c}\text { Sparge } \\
\text { Tube } \\
\text { Height } \\
\begin{array}{c}\text { Inches } \\
\text { from } \\
\text { bottom }\end{array}\end{array}$} & \multicolumn{2}{|c|}{$\begin{array}{l}\text { Pour } \\
\text { Flowrate }\end{array}$} & $\begin{array}{c}\text { Pour } \\
\text { Flowrate } \\
\text { Difference }\end{array}$ & \multicolumn{2}{|c|}{$\begin{array}{l}\text { Ln Content } \\
\text { of Glass }\end{array}$} & \multirow{3}{*}{$\begin{array}{c}\begin{array}{c}\text { Ln } \\
\text { Content } \\
\text { Difference }\end{array} \\
\begin{array}{c}\text { Wt } \% \\
\text { oxide }\end{array}\end{array}$} \\
\hline & & & & \multicolumn{2}{|c|}{$\mathrm{Kg} / \mathrm{hr}$} & \multirow[t]{2}{*}{$\mathrm{Kg} / \mathrm{hr}$} & \multicolumn{2}{|c|}{ Wt\% oxide } & \\
\hline & & & & Min & $\operatorname{Max}$ & & Min & $\operatorname{Max}$ & \\
\hline 1 & 1.5 & 90 & 1.0 & 22.1 & 31.0 & 8.9 & 47.1 & 48.6 & 1.5 \\
\hline 2 & 1.5 & 60 & 1.0 & 21.3 & 31.2 & 9.9 & 47.8 & 49.9 & 2.1 \\
\hline 3 & 1.5 & 45 & 1.0 & 21.2 & 37.3 & 16.1 & 46.7 & 50.4 & 3.7 \\
\hline 4 & 1.5 & 30 & 1.0 & 10.8 & 50.4 & 39.6 & 35.2 & 51.4 & 16.2 \\
\hline 5 & 1.0 & 60 & 1.0 & 12.9 & 44.5 & 31.6 & 37.9 & 49.8 & 11.9 \\
\hline 6 & 1.0 & 75 & 1.0 & 23.2 & 47.2 & 22.1 & 46.2 & 53.9 & 7.7 \\
\hline 7 & 1.5 & 75 & 1.0 & 24.2 & 39.4 & 15.2 & 46.1 & 51.8 & 5.7 \\
\hline 8 & 2.0 & 45 & 1.0 & 23.5 & 47.2 & 23.7 & 45.3 & 48.3 & 3.0 \\
\hline 9 & 1.5 & 75 & 1.75 & 24.4 & 41.6 & 17.2 & 44.5 & 48.1 & 3.6 \\
\hline
\end{tabular}

The general trends indicated by the data matched expections: higher sparge flowrates and longer sparge durations resulted in more uniform glass. These trends were followed by all runs except $\# 7$, which had a sparge rate of $1.5 \mathrm{scfh}$ and a sparge duration of 75 minutes. A review of the laboratory notebook and sample results did not indicate any condition which would cause the deviation from the general trend. The test runs were not duplicated to determine the amount of variance, therefore it is not known if the deviation shown by Run \#7 is within the expected variance of the process.

The difference in lanthanide content from the sample with the highest loading to the sample with the lowest loading was utilized to determine the amount of uniformity during each run. All runs except for Runs 4 and 5 showed acceptable uniformity (difference $<10 \mathrm{wt} \%$ oxide). At a sparge flowrate of $1.0 \mathrm{scfh}, 60$ minutes was determined to be the minimum sparge duration that produced uniform glass while increasing the flow to $1.5 \mathrm{scfh}$ decreased the minimum sparge 
duration to 45 minutes. In order to allow for instrument error and other margins for error, SRTC recommends that the melter be sparged at $1.5 \mathrm{scfh}$ of argon for 75 minutes.

The difference in maximum and minimum pour flowrates for each run was plotted in Figure 1 along with the difference in lanthanide content to determine if pour flowrate measurements could be used to predict homogeneity of the glass. As shown by the chart, pour flowrate difference follows the same trends as lanthanide content difference and can used to reliably predict whether or not the glass is uniform.

Figure 1. Difference in Pour Flowrate and Ln Content Versus Sparge Duration

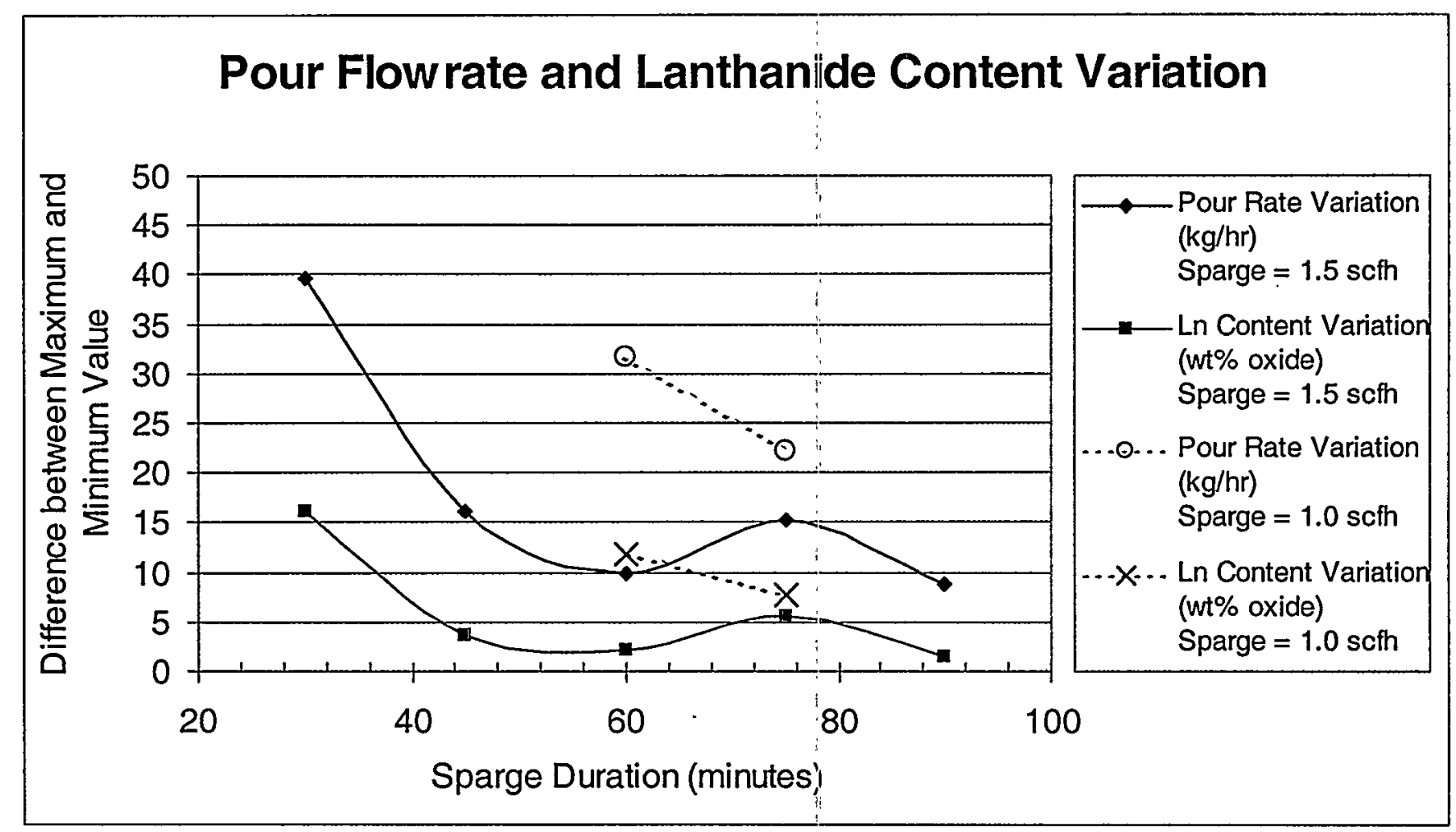


WSRC-TR-99-0462

Page 4 of 8

\section{REFERENCES}

1. Task Technical and QA Plan, WSRC-RP-99-0610, July 12, 1999.

2. J. E. Marra, et al. Americium-Curium Stabilization - 5" Cylindrical Induction Melter System Design Basis (U), SRT-AMC-99-0001, January 15, 1999.

3. T. M. Jones and D. C. Witt, CIM5 TTR Run Plan \#2 - Glass Bubbler Evaluation Task Number 1.07 (U), SRT-AMC-99-0203, September 30, 1999.

4. T. M. Jones and D. C. Witt, CIM5 TTR Glass Bubbler Evaluation Task Number 1.07 75 Minutes 1.5 SCFH (U), SRT-AMC-99-0209, October 26, 1999.

5. T. M. Jones and D. C. Witt, CIM5 TTR Glass Bubbler Evaluation Task Number 1.0745 Minutes @ 2.0 SCFH(U), SRT-AMC-99-0211, October 27, 1999.

6. T. M. Jones and D. C. Witt, CIM5 TTR Glass Bubbler Evaluation Task Number 1.07 Elevated Bubbler (U), SRT-AMC-99-0212, October 28, 1999.

7. 5" Cylindrical Induction Melter Development CIM 5 Laboratory Notebook, WSRC-NB98-0227.

8. D. C. Witt and T. M. Jones, CIM5 Phase III Base Process Development Results (U), WSRC-TR-99-00434, November 24, 1999. 


\section{Appendix A. Pour Flowrate and Lanthanide Content versus Pour Time Charts}

Run 1: 90 minute sparge at $1.5 \mathrm{SCFH}$ : Line is discontinuous due to missing data point.

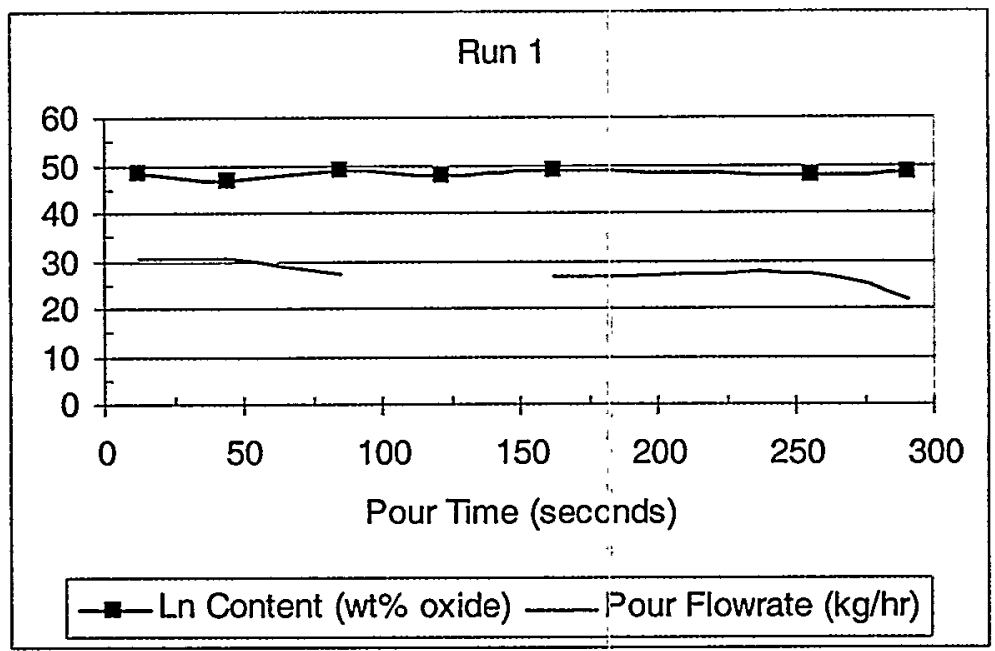

Run 2: 60 minute sparge at $1.5 \mathrm{SCFH}$

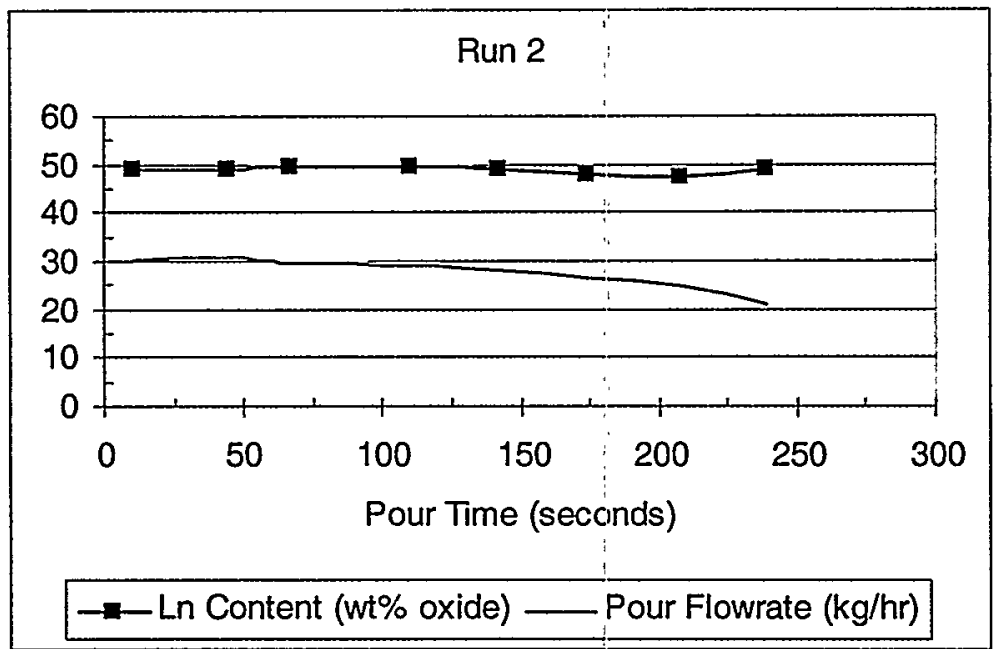

Run 3: 45 minute sparge at $1.5 \mathrm{SCFH}$

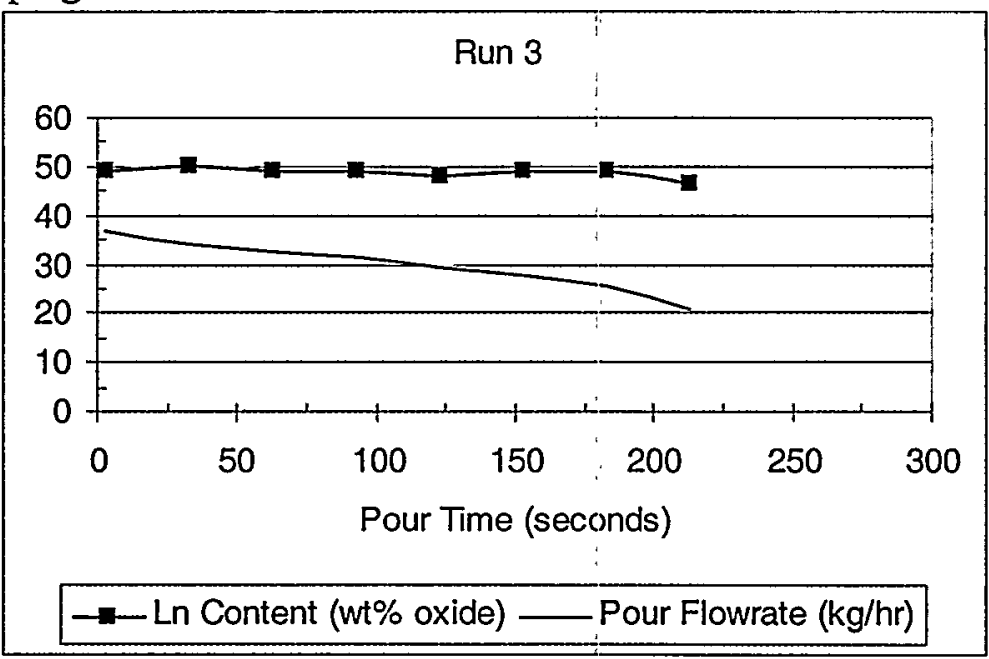


Run 4: 30 minute sparge at $1.5 \mathrm{SCFH}$

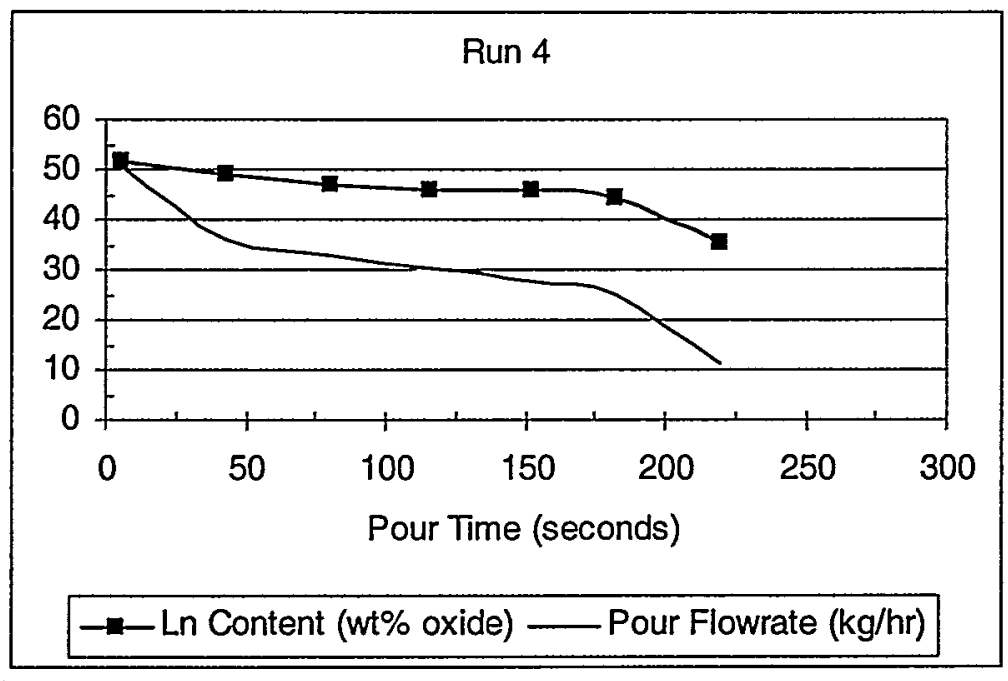

Run 5: 45 minute sparge at $1.0 \mathrm{SCFH}$

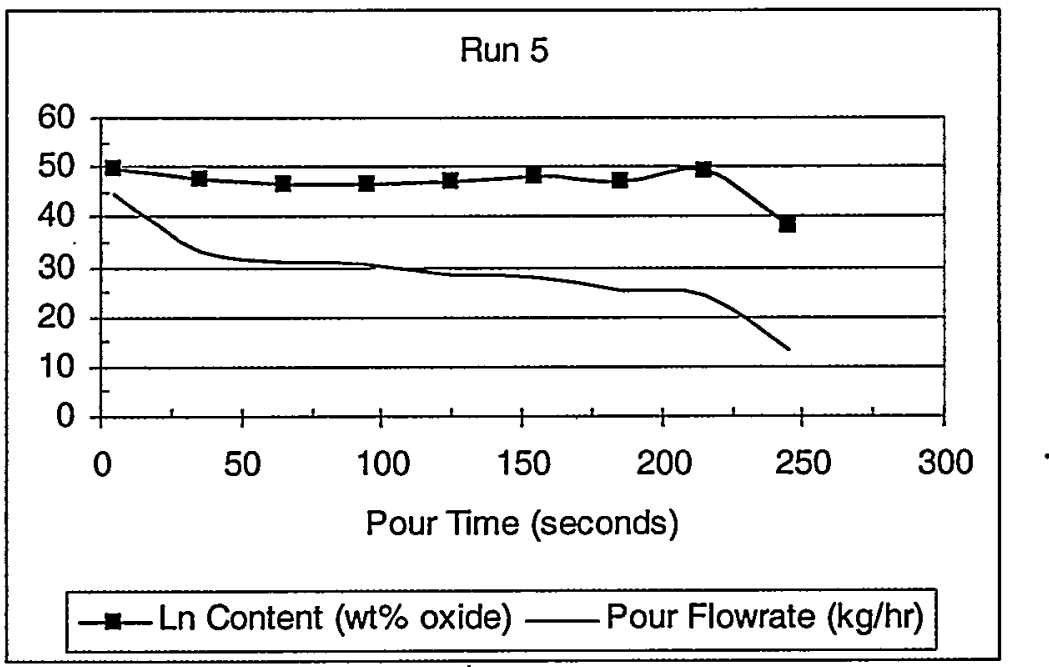

Run 6: 60 minute sparge at $1.0 \mathrm{SCFH}$

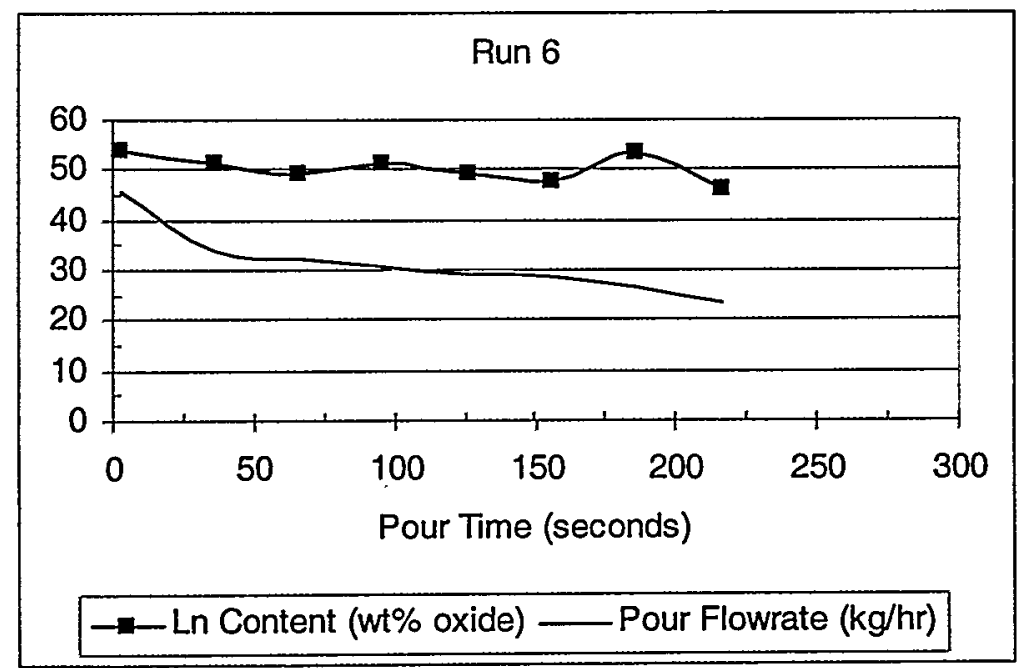


Run 7: 75 minute sparge at $1.5 \mathrm{SCFH}$

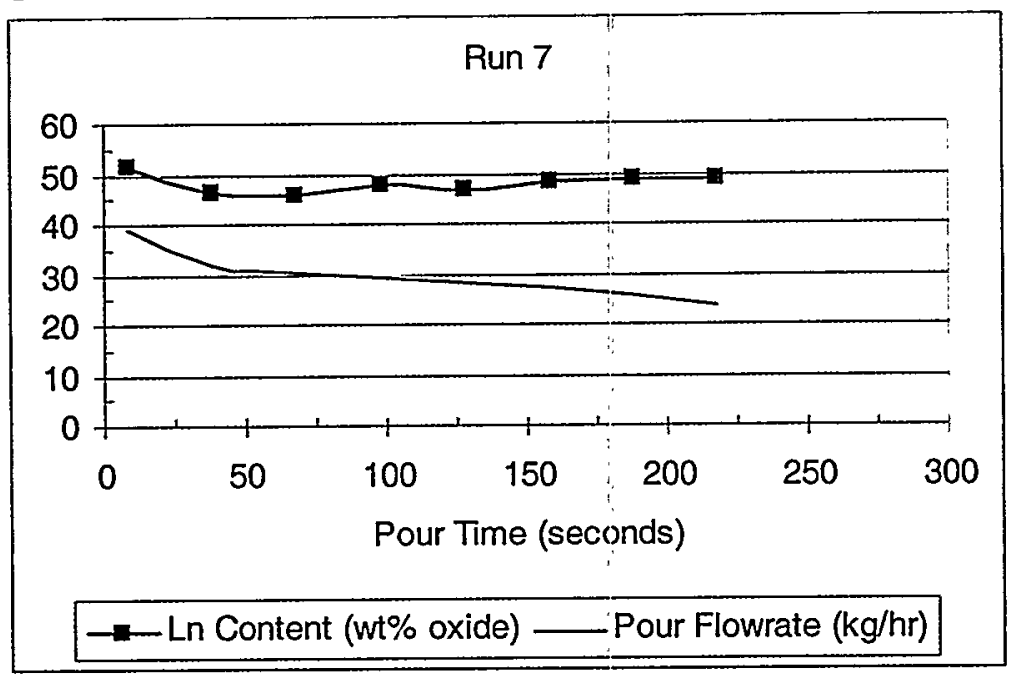

Run 8: 45 minute sparge at 2.0 SCFH

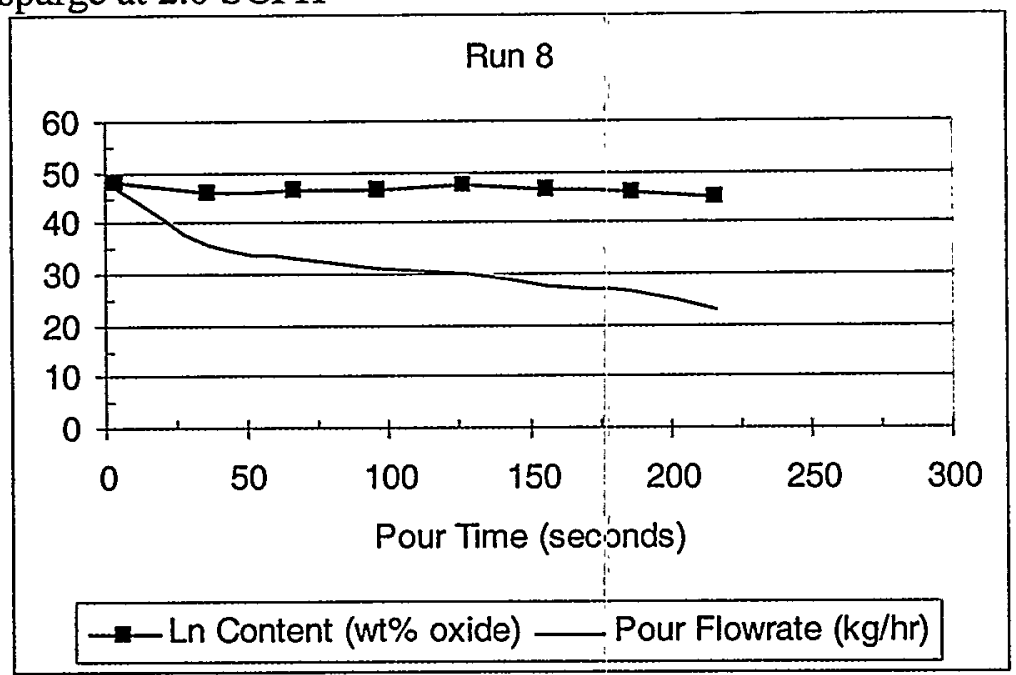

Run 9: 75 minute sparge at 1.5 SCFH with sparge dip tube raised to 1.75 "

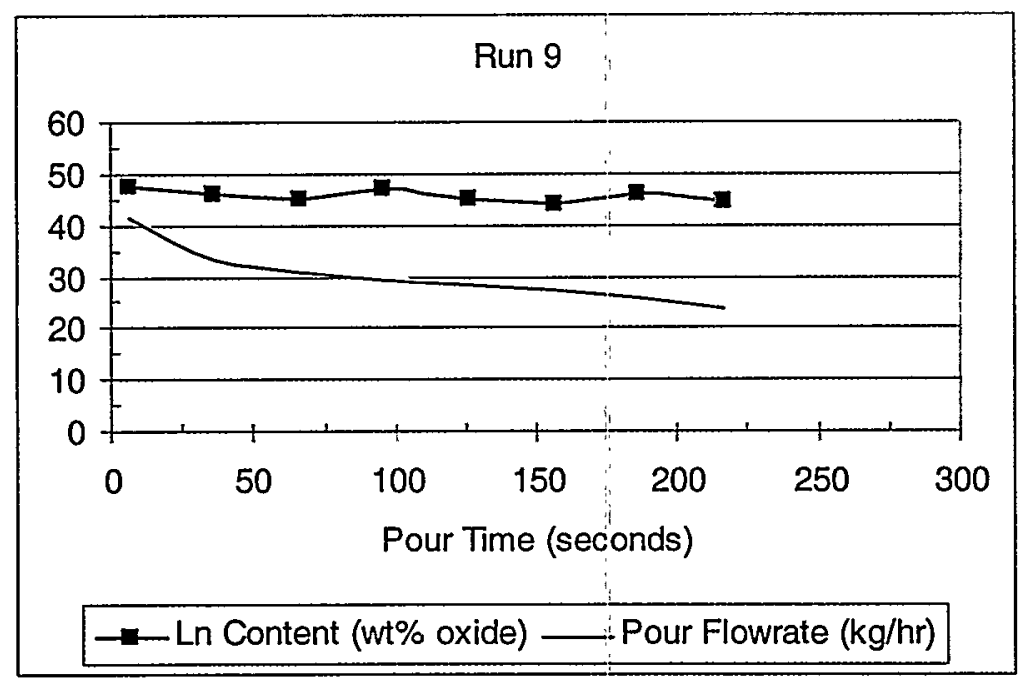




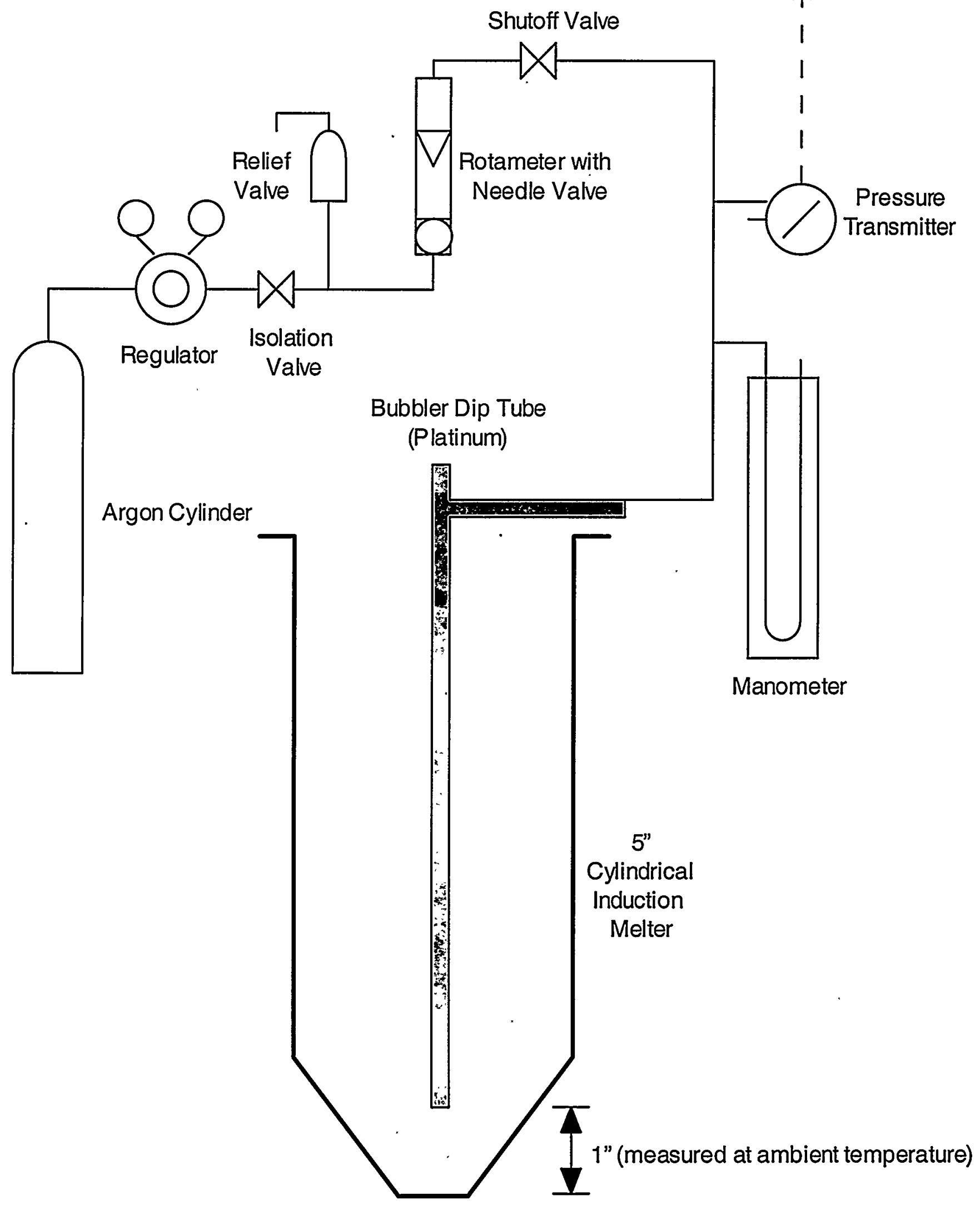




\section{DISTRIBUTION:}

L. M. Papouchado, 773-A

E. W. Holtzscheiter, 773-A

L. F. Landon, 704-1T

M. A. Baich, 704-1T

D. C. Witt, 704-1T

T. M. Jones, 704-1T

D. H. Miller, 704-1T

M. E. Stone, 704-1T

T. K. Snyder, 704-T

D. K .Peeler, 773-43A

C. B. Miller, 773-A

Am/Cm Files, 704-1T

STI, 703-43A (4) 